\title{
Mitochondrial DNA characterization of two Partamona species (Hymenoptera, Apidae, Meliponini) by PCR+RFLP and sequencing 1
}

\author{
Rute Magalhães BRITO, Maria Cristina ARIAS* \\ Departamento de Biologia, Instituto de Biociências, USP, São Paulo, SP, 05508-090, Brazil \\ Received 5 March 2004 - Revised 3 December 2004 - Accepted 8 December 2004 \\ Published online 9 August 2005
}

\begin{abstract}
We characterized the mitochondrial DNA of two stingless bee species of the genus Partamona. Partial restriction maps were obtained based on digestion of PCR amplified fragments with 8 restriction enzymes. Using Melipona bicolor mtDNA sequence as a model, we were able to amplify 12120 bp of $P$. mulata and $10300 \mathrm{bp}$ of $P$. helleri, about $65.5 \%$ and $55.7 \%$ of their mitochondrial genome, respectively. The digestion assays showed 16 restriction sites for $P$. mulata and 20 for P. helleri, some of which were exclusive to the genus and others shared with other Meliponini species. The main mitochondrial genes could be mapped and through sequencing analysis we verified that the intergenic region that occurs between the genes CO I and CO II in Apis is absent in Partamona.
\end{abstract}

Partamona / Meliponini / mtDNA / pcr / rflp / restriction map / stingless bee

\section{INTRODUCTION}

The tribe Meliponini is composed of stingless bees which are distributed in the tropical and southern subtropical areas of the World. The number of species is not well-defined although Michener (2000) estimated the occurrence of several hundred. Their ecological role as natural pollinators is unquestionable, and some species have been domesticated for commercial honey production (Nogueira-Neto, 1997).

This tribe presents a great diversity of nest architecture, intra colony population size, habitat, morphology and behavior. The recently revised genus Partamona Schwarz comprises 33 species and is broadly distributed, being found from southern Mexico to southern Brazil (Pedro and Camargo, 2003). A number of mor- phological, ethological and cytogenetical analyses have been used to infer evolutionary relationships within the group (Brito-Ribon et al., 1999; Azevedo and Zucchi, 2000; Brito et al., 2003; Pedro and Camargo, 2003). As a result four major phylogenetic groups have been defined within the genus: bilineatalepiphytophila, musarum, nigrior and cupira (Pedro and Camargo, 2003). The inclusion of nest architecture information improved the resolution of the phylogenetic relationships within the cupira group, in which only $P$. helleri does not build nests associated with termites, thus being positioned as sister species (Camargo and Pedro, 2003).

Mitochondrial DNA (mtDNA) analysis has been used widely in studies of population dynamics, biogeography and genetic relationships among species (Avise et al., 1987). However,

\footnotetext{
* Corresponding author: mcarias@ib.usp.br
}

1 Manuscript editor: Walter S. Sheppard 
for stingless bees these studies are only beginning, with just a few species belonging to the genera Plebeia Schwarz and Melipona Illiger having been studied so far (Francisco et al., 2001; Francisco, 2002; Silvestre et al., 2002; Weinlich et al., 2004).

This present work reports the partial characterization of the mitochondrial genome for two Partamona species of the cupira group: P. helleri (Friese) that has a large geographical distribution (from south to northeastern Brazil in the Atlantic Forest) and P. mulata (Moure) that is restricted to "cerrado" (savanna like) areas in central western Brazil. Also, although they belong to the same species group (cupira), $P$. helleri is not associated with termite nests.

\section{MATERIALS AND METHODS}

Individuals from one natural nest of Partamona mulata and one of $P$. helleri were collected, respectively, in Poconé, MT ( $\left.16^{\circ} 18^{\prime} \mathrm{LS}, 56^{\circ} 31^{\prime} \mathrm{LW}\right)$ and Viçosa, MG ( $\left.20^{\circ} 45^{\prime} \mathrm{LS}, 42^{\circ} 52^{\prime} \mathrm{LW}\right)$, Brazil, and used for the mtDNA analyses.

Total DNA was extracted using ten thoraces per tube following the methodology of Sheppard and McPheron (1991). For the mtDNA amplification, primers designed for Apis mellifera (Hall and Smith, 1991; Arias et al., 1998), Melipona bicolor (Silvestre, 2002) and others insects (Simon et al., 1994) were tested in a total of 116 combinations. The PCR reactions were performed in $50 \mu \mathrm{L}$, containing $0.5 \mu \mathrm{L}$ of DNA extraction, $5 \mu \mathrm{L}$ of $10 \mathrm{X}$ PCR buffer, $1.5 \mu \mathrm{L}$ of each primer $(20 \mu \mathrm{M}), 5 \mu \mathrm{L}$ of dNTPs ( $2 \mathrm{mM}$ each), $1.5 \mu \mathrm{L}$ of $\mathrm{MgCl}_{2}(50 \mathrm{mM})$ and $2.5 \mathrm{U}$ of Taq DNA polymerase (Invitrogen). The PCR amplifications followed the conditions described elsewhere (Francisco et al., 2001). However the annealing temperature and the cycle number were adjusted for each primer combination to improve the reaction specificity (Tab. I). The PCR products, $10 \mu \mathrm{L}$ of each reaction, were submitted to electrophoresis on $0.8 \%$ agarose gels. The gels were stained with ethidium bromide, visualized and photographed under UV light with Polaroid film.

Digestions of PCR fragments were carried out using 13 different restriction enzymes: $B c l \mathrm{I} ; B g l \mathrm{II}$; EcoR I; EcoR V; Hae III; Hind III; Pst I; Pvu II; Sca I; Xba I; Xho I (Boehringer Mannheim Biochemica); Cla I (Gibco BRL) and Nde I (New England Biolabs). The reactions were prepared with 3 to $5 \mu \mathrm{L}$ of the PCR amplified DNA and $5 \mathrm{U}$ of restriction enzyme following the manufactures instructions, and incubated overnight. For double digestions, the DNA was first digested overnight with one enzyme, precipitated, and then digested with the second enzyme.

The fragment amplified with the primer pair COI$\mathrm{IIF} / \mathrm{mtD} 18$ from both species (see Tab. I in Results) was cloned and sequenced. The cloning was carried out using the M-13 vector (pGEM T-Easy Promega) and the sequencing reactions were performed using a Big Dye Terminator kit (Applied Biosystem), according to their respective protocols. The single strand fragments originated were analyzed by an automated sequencer ABI-PRISM 310 (Perkin Elmer), and sequence alignments were performed with the programs Generunner V3.00 (Hastings Software) and MultiAlign 5.4.1 (Corpet, 1988).

\section{RESULTS AND DISCUSSION}

\subsection{Mitochondrial DNA fragments of Partamona mulata and $P$. helleri}

From the 116 primer pair combinations, 17 mtDNA regions amplified in $P$. mulata and 13 in $P$. helleri. Figure 1 presents the amplified fragments and their positions in comparison to the $M$. bicolor mtDNA genome (Silvestre, 2002). Some amplified regions overlapped. Table I summarizes those data and also the PCR conditions determined for each primer pair.

The sum of the fragments amplified, discounting overlapping stretches, is about 12120 bp for $P$. mulata and $10300 \mathrm{bp}$ for $P$. helleri. Assuming that Partamona mtDNA has the same genome size (18500 bp) as M. bicolor and other Meliponini (Francisco et al., 2001; Silvestre, 2002; Fernandes-Salomão et al., 2002; Weinlich et al., 2004), we were able to amplify $65.5 \%$ and $55.7 \%$, respectively (Fig. 1).

Some mtDNA regions did not amplify even using several primer combinations and modifications in the PCR conditions. One of the main regions absent in our map (Fig. 1) corresponds to the region encompassing the genes ND5 and ND4, although a short incomplete fragment was obtained for $P$. mulata. We believe that sequencing the adjacent regions and designing specific primers for Partamona mtDNA would be the best strategy for further sequencing attempts. A second area of absence in our map corresponds to the $\mathrm{A}+\mathrm{T}$ rich region, or control region, the size of which is quite difficult to estimate since no data have been obtained for any Meliponini species to date. 
Table I. PCR conditions and primer pairs that resulted in amplification of Partamona mtDNA. Gene content per region, fragment length (FI) in base pair (bp) expected (according to Melipona bicolor) and observed, annealing temperature (At) in Celsius degrees and (number of PCR cycles) are shown. (-): Not amplified.

\begin{tabular}{|c|c|c|c|c|c|c|c|}
\hline \multirow{2}{*}{$\begin{array}{l}\text { Fragment } \\
\text { (see Fig. 1) }\end{array}$} & \multirow[t]{2}{*}{ Primers } & \multirow[t]{2}{*}{ Principal genes } & \multirow{2}{*}{$\begin{array}{l}\text { Fl ( bp) } \\
\text { expected }\end{array}$} & \multicolumn{2}{|c|}{ At (No. of cycles) } & \multirow{2}{*}{$\begin{array}{c}\text { Fl (bp) } \\
\text { observed }\end{array}$} & \multirow{2}{*}{$\begin{array}{c}\text { Primer } \\
\text { reference }\end{array}$} \\
\hline & & & & P. mulata & P. helleri & & \\
\hline \multirow[t]{2}{*}{ I } & $\mathrm{mtD} 2$ & ND2, COI & 2200 & $43.5(45 \times)$ & $43(45 \times)$ & 2000 & $\mathrm{a}$ \\
\hline & mtD9 & & & & & & $\mathrm{a}$ \\
\hline \multirow[t]{2}{*}{ II } & $\mathrm{mtD} 7$ & COI, COII & 1600 & $43.5(45 \times)$ & $47(35 \times)$ & 1600 & $\mathrm{a}$ \\
\hline & COI-IIR & & & & & & $\mathrm{b}$ \\
\hline \multirow[t]{2}{*}{ III } & COI-IIF & COI, COII & 900 & $43(40 \times)$ & $43.5(35 \times)$ & 900 & $\mathrm{~b}$ \\
\hline & mtD18 & & & & & & $\mathrm{a}$ \\
\hline \multirow[t]{2}{*}{ IV } & mtD19 & ATP8, АTP6 & 1100 & $42(35 \times)$ & $42(35 \times)$ & 1200 & $\mathrm{a}$ \\
\hline & Seq11 & & & & & & $\mathrm{c}$ \\
\hline \multirow[t]{2}{*}{ V } & Seq10 & ATP8, АTP6 & 751 & $42(35 \times)$ & $42(35 \times)$ & 800 & $\mathrm{c}$ \\
\hline & Seq11 & & & & & & $\mathrm{c}$ \\
\hline \multirow[t]{2}{*}{ VI } & Seq24 & COIII & 600 & $42(35 \times)$ & - & 600 & $\mathrm{c}$ \\
\hline & mtD22 & & & & & & $\mathrm{a}$ \\
\hline \multirow[t]{2}{*}{ VII } & $5612 \mathrm{R}$ & COIII, ND3 & 1100 & $44(35 \times)$ & $43(40 \times)$ & 1100 & d \\
\hline & tPheF & & & & & & $\mathrm{c}$ \\
\hline \multirow[t]{2}{*}{ VIII } & Seq35 & ND5, ND4 & 900 & $41.5(35 \times)$ & - & 900 & $\mathrm{c}$ \\
\hline & tHisF & & & & & & $\mathrm{c}$ \\
\hline \multirow[t]{2}{*}{ IX } & Seq29R & ND4 & 400 & $42(35 \times)$ & $42(35 \times)$ & 400 & $\mathrm{c}$ \\
\hline & ND4F & & & & & & $\mathrm{c}$ \\
\hline \multirow[t]{2}{*}{$\mathrm{X}$} & $\mathrm{mtD} 24$ & ND4 & 667 & $42(35 \times)$ & $42(35 \times)$ & 700 & $\mathrm{a}$ \\
\hline & ND4F & & & & & & $\mathrm{c}$ \\
\hline \multirow[t]{2}{*}{ XI } & Seq38 & ND6 & 1400 & $42(35 \times)$ & - & 1200 & $\mathrm{c}$ \\
\hline & AMB16 & & & & & & $\mathrm{d}$ \\
\hline \multirow[t]{2}{*}{ XII } & Seq38 & ND6, cytB & 1400 & $42(35 \times)$ & $42(35 \times)$ & 1400 & $\mathrm{c}$ \\
\hline & mtD28 & & & & & & $\mathrm{a}$ \\
\hline \multirow[t]{2}{*}{ XIII } & Seq38 & ND6 & 1000 & $42(35 \times)$ & - & 1100 & $\mathrm{c}$ \\
\hline & mtD27 & & & & & & $\mathrm{a}$ \\
\hline \multirow[t]{2}{*}{ XIV } & mtD26 & cytB, ND1 & 1700 & $42(35 \times)$ & $42(35 \times)$ & 1700 & $\mathrm{a}$ \\
\hline & mtD30 & & & & & & $\mathrm{a}$ \\
\hline \multirow[t]{2}{*}{$\mathrm{XV}$} & $16 \mathrm{SF}$ & $16 \mathrm{~S}$ & 800 & $43.5(35 \times)$ & $43(35 \times)$ & 800 & $\mathrm{~b}$ \\
\hline & MEL 3 & & & & & & $\mathrm{c}$ \\
\hline \multirow[t]{2}{*}{ XVI } & $16 \mathrm{SF}$ & $16 \mathrm{~S}$ & 600 & $42(35 \times)$ & $42(35 \times)$ & 600 & $\mathrm{~b}$ \\
\hline & $16 \mathrm{SR}$ & & & & & & $\mathrm{b}$ \\
\hline \multirow[t]{2}{*}{ XVII } & mtD36 & $16 \mathrm{~S} / 12 \mathrm{~S}$ & 1800 & $53(35 \times)$ & $53(35 \times)$ & 1800 & $\mathrm{a}$ \\
\hline & $16 \mathrm{SR}$ & & & & & & $\mathrm{b}$ \\
\hline
\end{tabular}

a - Simon et al. (1994); b - Hall and Smith (1991); c - Silvestre (2002); d - Arias et al. (1998). 


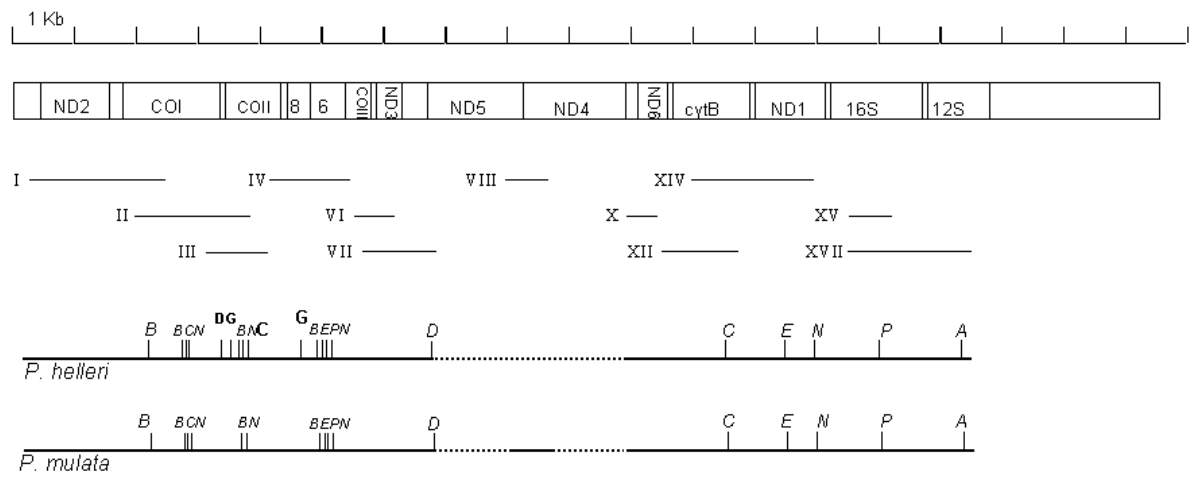

Figure 1. Linearized restriction maps, PCR-amplified regions for Partamona mulata and P. helleri and the main gene positions, using the Melipona bicolor mitochondrial genome as a guide. Amplified fragments are represented by bars and roman numbers (see Tab. I). Regions not amplified are represented by dotted lines. The A+T rich region and tRNAs were not represented. B, Bcl I; G, Bgl II; C, Cla I; E, EcoR I; A, Hae III; D, Hind III; N, Nde I; P, Pst I. Italic letters represent restriction sites conserved between both species. ND2, NADH dehydrogenase subunit 2; COI, cytochrome c oxidase subunit 1; COII, cytochrome c oxidase subunit 2; 8, ATP $F_{0}$ synthase subunit 8; 6, ATP $F_{0}$ synthase subunit 6; COIII, cytochrome c oxidase subunit 3; ND3, NADH dehydrogenase subunit 3; ND5, NADH dehydrogenase subunit 5; ND4, NADH dehydrogenase subunit 4; ND6, NADH dehydrogenase subunit 6; cytB, cytochrome B; ND1, NADH dehydrogenase subunit 1; 16S, large subunit ribosomal RNA; 12S, small subunit ribosomal RNA.

The sizes of the amplified fragments were similar to expected, according to the M. bicolor mtDNA sequence (Silvestre, 2002) (Tab. I), suggesting that the Partamona mitochondrial genome has the same main gene order. However, the Partamona fragment amplified by the primers $\mathrm{mtD} 2 / \mathrm{mtD} 9$ was $200 \mathrm{bp}$ less than in Melipona bicolor. This region comprises the ND2, 5'CO I and several tRNA genes. Transfer RNA genes are more likely to undergo translocations in the mtDNA genome than protein coding genes, a suggestion supported by the finding that at least $8 \mathrm{tRNA}$ translocations have been reported between A. mellifera and $M$. bicolor mtDNA (Silvestre, 2002; Silvestre et al., 2002). Thus this phenomenon may be quite frequent in bees and explain the length differences observed, since this mtDNA region comprises several tRNA genes. This needs to be further investigated by sequencing.

As described for Plebeia (Francisco et al., 2001) and M. bicolor (Silvestre, 2002), the Partamona species did not have an intergenic region between the $\mathrm{COI}$ and $\mathrm{COII}$ genes. The absence of the intergenic region in $P$. mulata and $P$. helleri was inferred initially by a fragment length, that was $300 \mathrm{bp}$ shorter than that described in A. mellifera (but similar to those observed in Plebeia and Melipona). This region was sequenced from both Partamona species (GenBank accession numbers: AY497503 and AY497504), and a total of 924 bp was aligned. The similarity level between $P$. helleri and $P$. mulata was estimated at $95.15 \%$ and 17 transversions, 23 transitions and 5 indels were verified. Sequence comparison between $P$. mulata and $M$. bicolor showed $90.7 \%$ similarity, 57 transversions, 23 transitions, and 6 indels, and with $P$. helleri $92.1 \%$ similarity, 48 transversions, 22 transitions and 3 indels. The nucleotide sequence corresponds to the 3'COI, tRNA $^{\text {Leu }}$ and 5'COII genes, and no single nucleotide was found between the tRNA ${ }^{\mathrm{Leu}}$ and 5'COII genes, which would characterize the intergenic region. In A. mellifera this region was first described by Crozier et al. (1989), and later Cornuet et al. (1991) verified that it has a high level of length variation among $A$. mellifera subspecies (ranging from 200 to $650 \mathrm{bp}$ ). Moreover, Cornuet et al. (1991) proposed that this region may function as an extra mtDNA origin of replication, based on its secondary structure. The lack of an intergenic region in Plebeia (Francisco et al., 2001), Melipona (Silvestre, 2002; Weinlich et al., 2004) and Partamona (present work) suggests that it is a conserved evolutionary characteristic among the stingless bees. 


\subsection{Partial restriction maps of Partamona mulata and P. helleri}

Of the 12 restriction enzymes used on all fragments, three (EcoR V; Sca I, and Xho I) did not cut in either species. The enzyme $P v u$ II was tested only on the mtD36/16SR fragment and no cleavage was observed. Sixteen restriction sites were detected in $P$. mulata and 20 in $P$. helleri, corresponding to 94 and 118 base pairs, respectively. Partial restriction maps are shown in Figure 1. Some restriction sites were found only in Partamona and not in Melipona and Plebeia. These included: $\mathrm{Bgl} \mathrm{II}$; Cla I; Hind III; Nde I, in fragment II (COI-COII) (Fig. 1); $B c l \mathrm{I} ; B g l$ II; $P s t$ I in IV (COII/ATPase 6 and 8 ) and Nde I in XIV (cytB and ND1). Moreover, some of those above mentioned sites were exclusive for $P$. helleri; such as $B g l \mathrm{II}$ and Hind III in II; and $B g l$ II in IV (Fig. 1). However, restriction site differences that appear fixed must be considered premature until surveys of population samples are completed.

Comparing our results to mtDNA restriction maps previously described for A. mellifera (Crozier and Crozier, 1993), Plebeia (Francisco et al., 2001) and Melipona (Weinlich et al., 2004), we verified that some restriction sites seem to be very conserved within corbiculate bees, such as: $B c l$ I sites in fragment II; EcoR I and Cla I in XIV and Pst I in XV (Fig. 1).

Some restriction sites were shared exclusively among bees from the tribe Meliponini such as: Cla I site in fragment III (but not in Melipona rufiventris and P. mulata); Hind III in fragment VII except for Melipona melanoventer and M. rufiventris; and Hae III in fragment XVII. We also found Partamona sites that were shared with one other species or genus: $B c l$ I and Nde I in fragment III with $A$. mellifera; Nde I in fragment IV with Plebeia except Plebeia saiqui; and one Cla I site on fragment II shared only with Plebeia sp.

The PCR+RFLP technique employed here provides the first molecular characterization of the mitochondrial genome of Partamona species. We were able to show that, in spite of Taq polymerase errors, it is possible to use this technique to map restriction sites as an alternative to Southern blot procedures. This PCR based method has some clear advantages over Southern blot mapping, as the latter can require a probe with high specificity, considerably more sample DNA to conduct the restriction digestions and more time and labor. Taq polymerase errors are easily resolved by repeating doubtful results, digesting PCR products from different reactions or even digesting other fragments that overlap with the suspect one. The potential of PCR+RFLP to assess genetic variability has been demonstrated in various studies on birds, lagomorpha, rodents, primates and fishes (Lovette et al., 1999; Mamuris et al., 2001; Perwitasari-Farajallah, 2001; Ittig et al., 2002; Papasotiropoulos et al., 2002). We plan to further use this technique to analyze mitochondrial haplotypes in population genetics studies of the Meliponini.

The data obtained here constitutes the first step toward haplotype recognition that will be useful in population genetic studies of Partamona helleri and P. mulata. The variability found in the mtDNA of these species also suggests that this methodology can be used to investigate phylogenetic relationships within and among Partamona groups.

\section{ACKNOWLEDGEMENTS}

We are grateful to Núcleo de Estudo da Fauna (NIEFA) - Universidade Federal de Mato Grosso for the great cooperation; to Dr. Lucio A.O. Campos of Universidade Federal de Viçosa for providing Partamona helleri specimens; to Mr. João Losano (Piuval Farm, Poconé - MT - Brazil) for allowing us to collect $P$. mulata specimens at his private property; to Susy Coelho for technical support; and to Dr. Walter Steven Sheppard for his comments and English revision. This work was financially supported by FAPESP.

Résumé - Caractérisation de l'ADN mitochondrial de deux espèces de Partamona (Hymenoptera, Apidae, Meliponini) par PCR + RFLP et séquençage. Le genre Partamona comprend 33 espèces et sa large répartition s'étend du sud du Brésil et du Paraguay jusqu'au Pérou et au sud du Mexique (Pedro et Camargo, 2000). On a essayé de tirer des conclusions sur l'évolution de ce groupe d'abeilles, bien que le faible niveau de variabilité trouvé n'autorise que la détermination des groupes phylogénétiques principaux au sein du genre. Les analyses d'ADN mitochondrial (ADNmt) ont pourtant été utilisées dans des études de parenté génétique parmi les espèces appartenant à la tribu des Meliponini et ont montré une variabilité aux niveaux intergénérique, interspécifique et intraspécifique. Le but du présent travail était de caractériser 
l'ADNmt de deux espèces d'abeilles du genre Partamona. En utilisant comme modèle la séquence de l'ADNmt de Melipona bicolor, nous avons pu amplifier $12120 \mathrm{pb}$ de d'ADNmt de $P$. mulata et $10300 \mathrm{pb}$ de celui de $P$. helleri, ce qui correspond respectivement à $65,5 \%$ et $55,7 \%$ de leur génome mitochondrial total (Tab. I et Fig. 1). L'absence de région intergénique entre les gènes cytochrome oxydase I (COI) et cytochrome oxydase II (COII) a été confirmée par le séquençage. Cette absence chez Partamona et chez d'autres Meliponini suggère qu'il s'agit d'un caractère phylogénétique conservé parmi les abeilles sans aiguillon. Des cartes partielles ont été construites d'après la digestion par 8 enzymes de restriction des fragments amplifiés par PCR. Les tests de digestion ont montré l'existence de 16 sites de restriction pour $P$. mulata et de 20 pour $P$. helleri (Fig. 1), certains sites étant limités au genre alors que d'autres sont partagés avec d'autres espèces de Meliponini. Nous pensons que les analyses moléculaires d'ADNmt fourniront d'autres données afin de mieux établir la relation génétique au sein des espèces de Partamona et entre elles.

Partamona / Meliponini / abeille sans aiguillon / ADNmt / carte de restriction / PCR / RFLP

Zusammenfassung - Eigenschaften der Mitochondrien DNA von zwei Partamona Arten (Hymenoptera, Apidae, Meliponini) nach PCR+RFLP und Sequenzierung. Die Gattung Partamona umfasst 33 Arten und ist weit verbreitet, von Südbrasilien und Paraguay bis Peru und Südmexiko (Pedro und Camargo, 2003). Es wurde versucht, auf die Evolution dieser Bienengruppe zu schließen, obwohl die geringe Variabilität nur die Bestimmung der Hauptgruppen innerhalb dieser Gattung ermöglichte. Erfolgreiche Analysen der Mitochondrien DNA (mtDNA) ergaben sich jedoch bei Studien über die genetische Verwandtschaft zwischen Arten der Meliponini. Sie ergaben eine Variabilität sowohl zwischen den Gattungen, als auch zwischen und innerhalb der Arten. Deshalb sollte in dieser Arbeit die mtDNA von 2 Arten der Gattung Partamona charakterisiert werden. Als Modell benutzten wir die mtDNA Sequenz Melipona bicolor, und konnten so $12120 \mathrm{bp}$ von $P$. mulata und 10300 bp der $P$. helleri mtDNA amplifizieren. Das sind etwa 65,5 \% bzw. 55,7 \% des gesamten Mitochondrien Genoms (Tab. I und Abb. 1). Wir fanden keine Sequenzen zwischen den Genen der Cytochrom Oxidase I (COI) und Cytochrom Oxidase II (COII). Dieses Fehlen eines Bereichs zwischen den Genen bei Partamona sowie bei anderen Arten der Meliponini weist darauf hin, dass es sich hierbei um ein evolutionskonservatives Merkmal bei Stachellosen Bienen handelt. Partielle Restriktionskarten wurden durch die Verdauung mit 8 Restriktionsenzymen von mit PCR amplifizierten Fragmenten erstellt. Die Verdauungstests ergaben 16 Schnittstellen bei P. mulata und 20 bei P. helleri (Abb. 1). Einige Schnittstellen waren auf die Gattung beschränkt, einige waren auch bei andere Arten der Meliponini vorhanden. Wir glauben, dass die molekulare Analyse der mtDNA zusätzliche Daten aufzeigen wird, um die genetische Verwandtschaft innerhalb und zwischen den Partamona Arten besser darzustellen.

Partamona / Meliponini / mtDNA / pcr / rflp / Restriktionskarten / Stachellose Biene

\section{REFERENCES}

Arias M.C., Francisco F.O., Silvestre D., Weinlich R., Sheppard W.S. (1998) Utilização de pares de primers específicos para amplificação integral do genoma mitocondrial de abelhas Apis mellifera, Anais do III Encontro Sobre Abelhas, Ribeirão Preto, Brasil, p. 271

Avise J.C., Arnold J., Ball R.M., Bermingham E., Lamb T., Niegel J.E., Reeb C.A., Saunders N.C. (1987) Intraspecific phylogeography: The mitochondrial DNA bridge between population genetics and systematics, Annu. Rev. Ecol. Syst. 18, 489-522.

Azevedo G.G., Zucchi R. (2000) Relações etológicas entre Partamona Schwarz e Parapartamona Schwarz (Hymenoptera, Apidae, Meliponinae), Anais do IV Encontro Sobre Abelhas, Ribeirão Preto, Brasil, pp. 258-264.

Brito-Ribon R.M., Miyazawa C.S., Pompolo S.G. (1999) First karyotype characterization of four species of Partamona (Friese, 1980) (Hymenoptera, Apidae, Meliponinae) in Mato Grosso state - Brazil, Cytobios 100, 19-26.

Brito R.M., Caixeiro A.P.A., Pompolo S.G., Azevedo G.G. (2003) Cytogenetic data of Partamona peckolti (Hymenoptera, Apidae, Meliponini) by $\mathrm{C}$ banding and fluorochrome staining with DA/ $\mathrm{CMA}_{3}$ and DA/DAPI, Genet. Mol. Biol. 26, 5357.

Camargo J.M.F., Pedro S.R.M. (2003) Meliponini neotropicais: o gênero Partamona Schwarz, 1939 (Hymenoptera, Apidae, Apinae) - bionomia e biogeografia, Rev. Brasil. Entomol. 47, 311-372.

Cornuet J.-M., Garnery L., Solignac M. (1991) Putative origin and function of the intergenic region between COI and COII of Apis mellifera L. mitochondrial DNA, Genetics 1128, 393-403.

Corpet F. (1988) Multiple sequence alignment with hierarchical clustering, Nucleic Acids Res. 16, 10881-10890.

Crozier R.H., Crozier Y.C. (1993) The mitochondrial genome of the honeybee Apis mellifera: complete sequence and the genome organization, Genetics 133, 97-117.

Crozier R.H., Crozier Y.C., Mackinlay A.G. (1989) The CO-I and CO-II region of honeybee mitochondrial DNA: evidence for variation in insect mitochondrial evolutionary rates, Mol. Biol. Evol. 6, 399-411. 
Fernandes-Salomão T.M., Muro-Abad J.I., Campos L.A.O., Araújo E.F. (2002) Mitochondrial and nuclear DNA characterization in the Melipona species (Hymenoptera, Meliponini) by RFLP analysis, Hereditas 137, 229-233.

Francisco F.O. (2002) Diversidade genética de populações da abelha sem ferrão Plebeia remota: análise do DNA mitocondrial e microssatélites, MSc thesis, Instituto de Biociências, Universidade de São Paulo, São Paulo, SP

Francisco F.O., Silvestre D., Arias M.C. (2001) Mitochondrial DNA characterization of five species of Plebeia (Apidae: Meliponinae): RFLP and restriction maps, Apidologie 32, 323-332.

Hall H.G., Smith D.R. (1991) Distinguishing African and European honeybee matrilines using amplified mitochondrial DNA, Proc. Natl. Acad. Sci. USA 88, 4248-4552.

Ittig R.E.G., Theiler G.R., Gardenal C.N. (2002) A contribution to the subgeneric systematics of Oligoryzomys (Rodentia, Muridae) from Argentina by means of PCR+RFLP patterns of mitochondrial DNA, Biochem. Syst. Ecol. 30, 23-33.

Lovette I.J., Bermingham E., Rohwer S., Wood C. (1999) Mitochondrial restriction fragment length polymorphism (RFLP) and sequence variation among closely related avian species and the genetic characterization of hybrid Dendroica warblers, Mol. Ecol. 8, 1431-1441.

Mamuris Z., Sfougaris A.I., Stamatis C. (2001) Genetic structure of Greek brown hare (Lepus europaeus) populations as revealed by mtDNA RFLP-PCR analysis: implications for conserving genetic diversity, Biol. Conserv. 1001, 187-196.

Michener C.D. (2000) The Bees of the World, The Johns Hopkins University Press, Baltimore, MD, USA

Nogueira-Neto P. (1997) Vida e Criação de Abelhas
Indígenas Sem Ferrão. Nogueirapis, São PauloSP, Brazil.

Papasotiropoulos V., Klossa-Kilia E., Kilias G., Alahiotis S. (2002) Genetic divergence and phylogenetic relationships in grey mullets (Teleostei: Mugilidae) based on PCR-RFLP analysis of mtDNA segments, Biochem. Genet. 40, 71-86.

Pedro S.R.M., Camargo J.M.F. (2003) Meliponini neotropicais: o gênero Partamona Schwarz, 1939 (Hymenoptera, Apidae), Rev. Bras. Entomol. 47, $1-117$.

Perwitasari-Farajallah D. (2001) Genetic characterization of long-tailed macaques (Macaca fascicularis) on Tabuan island, Indonesia, Primates 42, 141-152.

Sheppard W.S., McPheron B.A. (1991) Ribosomal DNA diversity in Apidae, in: Smith D.R. (Ed.), Diversity in the Genus Apis, Westview Press, Oxford, pp. 89-102.

Silvestre D. (2002) Seqüenciamento e análise do genoma mitocondrial de Melipona bicolor (Hymenoptera, Apidae, Meliponini), MSc thesis, Instituto de Biociências, Universidade de São Paulo, São Paulo, SP.

Silvestre D., Francisco F.O., Weinlich R., Arias M.C. (2002) A scientific note on mtDNA gene order rearrangements among highly eusocial bees, Apidologie 33, 355-356.

Simon C., Frati F., Becknbach A., Crespi B., Liu H., Flook P. (1994) Evolution, weighting, and phylogenetic utility of mitochondrial gene sequences and a compilation of conserved polymerase chain reaction primers, Ann. Entomol. Soc. Am. 87, 651-701.

Weinlich R., Francisco F.O., Arias M.C. (2004). Mitochondrial DNA restriction and genomic maps of seven species of Melipona (Apidae: Meliponini), Apidologie 35, 365-370. 